\title{
THE IMPACT OF TELECOMMUNICATION GROWTH ON THE SERVICE SECTOR: A COINTEGRATION ANALYSIS
}

\author{
Dhanushka Thamarapani \\ Economics Department, Clark University, USA. \\ dthamarapani@clarku.edu.
}

\begin{abstract}
Using annual time series data of Sri Lanka this study examines the impact of telecommunication sector growth on the service sector growth. The methodology employed consists of the bivariate and multivariate cointegration approach to establish the long run equilibrium relationship and causality testing is employed to detect the direction of this relationship. The current study is the first of its kind to use annual secondary data to examine the long run relationship between telecommunications sector and service sector in Sri Lanka. I find statistical evidence for a positive long run equilibrium relationship between telecommunication sector growth and service sector growth which confirmed the research hypothesis. Finally, the possibility of one-way link between telecommunications sector growth and service sector growth was established through causality test. Based on these finding the current study emphasizes the need to target long term growth strategies in the telecommunication service sector for Sri Lanka.
\end{abstract}

Keywords: Telecommunication, Telephone Density Rate, Economic Growth, Sri Lanka

\section{Introduction}

Assessing the impact of telecommunication sector growth on economic growth has been addressed over the past decade in many countries owing to the rapid increase technological innovations. The link with technology opens telecommunication sector to innumerous avenues since new technology (ex. 3G, 3.5G high speed packed access (HSPA) technology) would translate to new development potentials. For example, there is emphasis on mobile commerce (M-Commerce) which would facilitate Small and Medium Scale Enterprises (SMEs) as a communication tool which uses network that provides access to direct marketing business.

Service sector has drawn a similar attention being the highest contributor to the overall GDP over the past years. Furthermore, within the service sector, telecommunication seems to be performing well. For example, the mobile phones subscribers' base has reached almost 17.2 million and it is revealed that the telephone density, the number of connections (both fixed and mobile connections) for every 100 persons, is 100.79 (Central Bank of Sri Lanka (2010) that implies the number of connections has surpassed the population. The waiting lists have plummeted and the expensive down payments are substituted by "easy installment" schemes. All of whichindicate of how telecommunications has managed to become a household necessity.

Thus being a country which is now experiencing an over the average growth in the telecommunications sector as compared to other countries in the region, telecommunication sector is still under developed in Sri Lanka. Economists around the world have paid special attention to examining the relationship as well as the direction of the relationship between the telecommunication sector growth and economic growth.

According to Waverman, Meschi andFuss (2005) at the beginning telecommunications promoted economic growth by cutting down transaction cost of individuals and firms. Röller and Waverman (2001) estimated the impact of investment in telecommunication infrastructure 
on GDP in the OECD countries and revealed a significant positive relationship between the two variables. Although the telephone penetration rates were quite low during 1970s and there was no usage of mobile phones, gradually the importance of telecommunications sector reached the developing world. Chakraborty and Nandi (2003) reveals that there is bi-directional causation and a long run equilibrium relationship. However, the frequent findings of positive correlation between these two variables were challenged by Straub et al (2008) with the finding of no significant link between infrastructure stock and economic growth.

Many cross country studies have examined the relationship between telecommunications infrastructure growth and economic growth and some of these studies have included Sri Lanka in their sample (for example, Fink et al.(2002), Torero et al.(2002)) However there is a gap of a country specific study especially with regard to the telecommunication sector's impact on the service sector. When Sri Lanka is included in a general sample the country specific features of the Sri Lankan telecommunications sector is dampened through averaging and generalization. Therefore it urges the need of conducting a study paying attention to the market behavior specific to Sri Lanka.

The remainder of the paper is organized as follows. Section two discusses the literature, followed by a summary of the telecommunications policy in Sri Lanka. Section four puts forth the model followed by the discussion of results. Section six concludes.

\section{Literature Review}

Considering the research that has been done so far it is evident that most of the studies tend to analyze the impact of telecommunication sector on the economic growth as a whole. The most common used methodology is the Annual Production Function. For example, Röller and Waverman (2001) demonstrate that telecommunications infrastructure significantly and positively affects economic growth using annual time series and cross sectional data for 21 OECD countries. Several more recent papers extended this analysis to the developing countries which yield consistent results (for example, Yoo (2002), Belaîd (2003); Waverman et al (2005)). The latter also reveals that mobile phones in less developed economies are playing the same role that fixed lines played in the richer economies in the 1970s and 1980s. Therefore mobile phones are substitutes for fixed lines in developing countries and complements fixed lines in developed countries.

Employing similar methodologyTorero et al. (2002) reveal a positive causal link between infrastructure and GDP in which the sample includes Sri Lanka. An extension of this study is attempted by Sridhar and Sridhar (2004) through the introduction of the mobile phone sector and concludes that the impact of telecommunication penetration on total output is significantly lower for developing countries than that reported for OECD countries in Röller and Waverman (2001) thus dismissing the convergence hypothesis as suggested by Mankiw et al. (1992).

In contrast, the work of Beil et al. (2003) based on investment and GDP data for USA, indicates that investment in the telecommunications industry is caused by, but does not cause, economic activity by employing Granger-Sims causality tests. In contrast Chakraborty and Nandi (2003) establish bi-directional causation and a long run equilibrium relationship between GDP and Telephone Density Rate (TDR). However they only account for the fixed lines thus overlooking the contribution of the mobile phone sector. There are other studies that have concentrated on similar topic using datasets from different parts of the world (for example, Madden and Savage (1997) - Central and Eastern Europe; Seethepalli et al. (2008), Straub et al. (2008) - East Asia; Fink et al. (2002) - 86 developing countries) although there is debate on the exact sign and magnitude of the correlation. 
Some studies analyzing the impact of infrastructure as a whole on economic growth (Calderón and Servén (2004);Canning and Pedroni (2004)) conclude that infrastructure stock positively affects economic growth while Canning (1999) highlights the effect of network externalities. There are some studies that look at specific countries (ex. Narayana (2008) and Vijayamohanan (2008)). In the case of Sri Lanka, although telecommunications infrastructure remains underprovided this sector is nonetheless one of the fastest growing and technological improvements are occurring at a rapid rate (de Mel \& Wijayasiri (2008)). However there is still the absence of studies looking at the exact contribution of telecommunication sector. According to Munnell (1992) there is potential for policy implications in this sector. Thus the present study attempts to fill the gap in the available literature by examining the long run effect of growth in telecommunications sector (which accounts for both fixed and mobile telephony) on the growth of the service sector which has not been addressed with respect to Sri Lanka.

\section{The Evolution of the Telecommunications Policy in Sri Lanka}

Fixed telephony has shouldered the development of the telecommunications industry since economic liberalization in 1977. Despite the growth the waiting periods were long; the transmission quality was poor and the high initial cost resulted in inadequate access to telecommunications. The situation gradually changed with the introduction of reforms as well as competition. Instead of owning a traditional fixed wire line, now the customer has the option to choose from wireless local loop (WLL) operators as well as code division multiple access (CDMA) phones or even mobile phones with distinctive features like $3 \mathrm{G}$ and video conferencing. The customers were given a better service and consequently the industry grew at a rapid scale drawing attention for professional intervention. Such interventions resulted in establishing regulatory bodies and opening up of the industry to accommodate competition. The gradual growth of the service sector has now reached its climax being the highest contributor to the overall GDP. Within the service sectorthe performance of the telecommunications has dramatically improved. Figure 1 is a simultaneous look at the growths in these two sectors. The tele-mobile density rate (TMDR) is the number of fixed lines and mobile phones per 100 persons $^{4}$. The underprovision of telephone service was continuously prevalent that in 1996 only 50 percent of the expressed demand was catered by the Sri Lanka Telecom (SLT) (Central Bank 1996). Nonetheless alandmark in telecommunications industry was the partial privalization of SLT by Nippon Telegraph and Telephone (NTT) in1997 which contirubuted to the conspequous growth in telecommunications. Thus by 1999 Sri Lanka had the most deregulated telecommunications sector in South Asia (Central Bank 1999). The increasing significance of telecommunications is demonstrated in the Figure 2 which compares the contribution of the transport, storage and communications sector in 1978 and 2010 in order to see the growth pattern over 30 years. At present transport, storage and communications sector is the second largest contributor to the service sector GDP.

The actual reforms in telecommunications sector began in 1980 through the de-linking of post and telecommunication services (de Mel \& Wijayasiri 2008) which resulted in breaking away from the Post, Telegraph and Telephone (PTT) model. The entrance of the first private operator into the market occurred in 1989 when Celltel, a mobile operator, was licensed. However, the reforms transpired in 1991 with the Telecommunications Act No. 25 which converted then Department of Telecommunication (DoT) to Sri Lanka Telecommunication Corporation (SLT) that was owned by the government. The act of 1991 was amended in 1996 by the Sri Lanka Telecommunications Act No. 27 thorough which the Telecommunications Regulatory Commission 
of Sri Lanka (TRC) was established. Among the plans for the future development of the industry TRC has set goals to achieve a 16 million mobile phone subscriber base by 2016 (TRC 2006). In the year of TRC's establishment, SLT was transformed into a public company as a preliminary step towards privatization (Jayasuriya \& Knight-John 2002). The following year, in 1997, the government sold 35 per cent of its shareholding to NTT and another 3.5 per cent of shares were distributed among the employees of SLT. In mobile telephony the new players have been entering over the past decade. As at August 2011 there were five mobile service providers in operation: Dialog (1995), Mobitel (2002) $)^{5}$, Hutch (2004), Airtel (2008) and Etisalat $(2009)^{6}$. Nonetheless telecommunications industry is still in need of comprehensive policies to promote its growth. Thus implementation of up to date policies has become a timely necessity in this industry.

\section{Research Methods}

Annual data for the period of $1978-2010$ was collected from Statistical Abstracts published by the Department of Census and Statistics as well as from the Annual Reports of the Central Bank of Sri Lanka. This study is the first of its kind to use annualsecondary data for the test of cointegration specifically between telecommunications sector and service sector.

The study comprises of all the variables in their growth rates form. Service sector growth $\left(S_{t}\right)$ is defined as service sector Real GDP growth. The growth in the telecommunication sector is measured by the growth in Tele-Mobile Density Rate $\left(\mathrm{TMDR}_{\mathrm{t}}\right)$ which represents the growth in number of fixed lines and mobile phones per 100 persons. Growth rates of the Real GDP of other sub sectors of the service sector, i.e. Wholesale and Retail Trade $\left(\mathrm{W}_{\mathrm{t}}\right)$, Banking, Insurance and Real Estate $\left(\mathrm{B}_{\mathrm{t}}\right)$, Ownership of Dwellings $\left(\mathrm{Od}_{\mathrm{t}}\right)$, Public Services $\left(\mathrm{Pb}_{\mathrm{t}}\right)$ and Private Services $\left(\mathrm{Pr}_{\mathfrak{t}}\right)$ are also included to this model.
Cointegration analysis of bivariate approach (Engle \& Granger 1987) and multivariate approach (Johansen 1988) are adopted in this study. A simple Cobb Douglas production function employed by Canning and Pedroni (2004) based on Barro (1990) is modified and used to highlight the impact of telecommunications infrastructure on economic growth. Thus, the aggregate output $Y$, at time $\mathrm{t}$ is produced utilizing telecommunication infrastructure capital, $G$, other capital, $K$, and labor $L$, such that

$$
Y_{t}=A_{t} K_{t}^{\alpha} G_{t}^{\beta} L_{t}^{1-\alpha-\beta},
$$

where $A_{t}$ is total factor productivity at time $\mathrm{t}$. According to equation 1 , the growth in telecommunications infrastructure results in achieving higher economic growth. The present study looks at the contribution to the service sector growth which is a significant component of the overall economic growth. First, time series properties of the variables are tested. Then, cointegration analysis is performed using the simple bivariate cointegration test proposed by Engle and Granger in 1987. Thus service sector growth rate $\left(S_{t}\right)$ is regressed on growth in TeleMobile Density Rate (TMDR ${ }_{\mathrm{t}}$ ) as follows:

$$
s_{t}=c_{t}+\beta \operatorname{TMDR}_{t}+e_{t},
$$

which can be alternatively expressed as :

$e_{t}=S_{t}-c_{t}-\beta$ TMDR $_{t}$

According to Engle Granger Approach, Augmented Dickey Fuller (ADF) test on the residual $\left(e_{t}\right)$ is performed to find out whether the linear combination of these two variables are stationary. If the null hypothesis is rejected, then the linear combination of the service sector growth $\left(\mathrm{S}_{\mathrm{t}}\right)$ and TMDR growth $\left(\mathrm{TMDR}_{\mathrm{t}}\right)$ is stationary and therefore there exists a long run (equilibrium) relationship between these two variables.

The Error Correction Models (ECM) is used to estimate the short run dynamics between 
telecommunication sector growth and service sector growth in Sri Lanka. When two variables are cointegrated, though they are in equilibrium in the long run, in the short run they may be in disequilibrium. Therefore the residual $\left(e_{t}\right)$ in equation 3 can be treated as an equilibrium error.This error term can be used to tie the short run behavior of service sector growth $\left(\mathrm{S}_{\mathrm{t}}\right)$ to the long run value. According to the Granger Representation Theorem (Engle and Granger (1987)) if two variables are cointegrated, then the relationship between those two can be expressed in an ECM as follows:

$\Delta \mathrm{S}_{\mathrm{t}}=\alpha_{0} 0^{+} \alpha_{1} \Delta \mathrm{TMDR}_{\mathrm{t}}+\alpha_{2} \mathrm{e}_{\mathrm{t}-1}+\eta_{\mathrm{t}}$,

where $e_{t-1}$ is the lagged error term of equation 2 . The absolute value of $\alpha 2$ decides how quickly the equilibrium is restored. It is the speed of adjustment coefficient. If $\alpha_{2}$ in equation 5 is statistically significant it could be concluded that service sector growth rate $\left(\mathrm{S}_{\mathrm{t}}\right)$ responds to disequilibria in the service sector growthtelecommunication sector growth relationship and the value of the coefficient $\alpha_{2}$ demonstrates how much of the disequilibrium is corrected annually.

It is often possible that there may be more than one cointegrating relationship among variables. In order to capture this aspect Johansen (1988) approach is employed. As pointed out by Hassan (2003) this approach considers the vector autoregressive (VAR) model of the following form

$$
\begin{aligned}
X_{t}= & \gamma+\Phi_{1} X_{t-1}+\Phi_{2} X_{t-2}+\ldots \\
& +\Phi_{k} X_{t-k}+\eta_{t}, \mathrm{t}=1,2, \ldots, \mathrm{T}
\end{aligned}
$$

where $X_{t}$ is a 7 by 1 vector containing all the growth rate variables in the Model 1. "In a VAR, each variable is 'explained' by its own lagged values, and the lagged values of all other variables in the system" (Hendry and Juselius (2000)). This test indicates the number of cointegrating vectors, $r$, in the system. In the process of estimation, the $r$ co-integrating relations are solved for the first $r$ variables in the
$X_{t}$ vector as a function of the remaining $k-r$ variables. Later this was developed to a Vector Error Correction Model (VEC) thus incorporating all the other variables in to the model in order to estimate their short run behavior. In the presence of more than one cointegrating relationship the VEC model is adopted that in the short term, deviations from the long term equilibrium is fed back on the changes in the dependent variables in order to force their movements towards the long term equilibrium (Hassan (2003)). Thus by using equation 4 the following VEC model is derived.

$$
\begin{aligned}
& \Delta X_{t}=\gamma+\Gamma_{1} \Delta X_{t-1}+\Gamma_{2} \Delta X_{t-2}+\ldots+ \\
& \Gamma_{k-1} \Delta X_{t-k+1}+\Pi X_{t-k}+\eta_{t}, \mathrm{t}=1, \ldots, \mathrm{T}
\end{aligned}
$$

where $\Delta X_{t}$ is the vector of first differences of the variables in growth rate model, the $\Gamma \mathrm{s}$ are estimated parameters, $\eta_{\mathrm{t}}$ is a vector of unanticipated movements in $X_{t}$ and $\Pi$ is the long term parameter matrix.

As the final step the direction of the relationship between telecommunication sector growth and service sector growthis established through employing Granger Causality test (Granger (1969)) with the objective of finding whether the relationship (if any) between these two variables is uni-directional or bi-directional. Hence the following formulae are derived from the standard:

$$
\begin{aligned}
& S_{t}=\sum_{i=1}^{k} \varphi_{1 i} T_{M D R_{t-i}}+\sum_{i=1}^{k} \varphi_{2 i} S_{t-i}+u_{1 t} \\
& T M D R_{t}=\sum_{i=1}^{k} \varphi_{3 i} T M D R_{t-i}+\sum_{i=1}^{k} \varphi_{4 i} S_{t-i}+u_{2 t}
\end{aligned}
$$

where the lag length was determined by the AIC $\&$ SIC criterion. The rejection of both null hypotheses would indicate bi-directional causality. If a single null hypothesis is rejected it would proveuni-direction. 


\section{Results and Discussions}

The unit root test isperformed to find out the order of integration of the variables in the study. The ADF test results are summarized in Table 1. Thus all the variables are I(1) in the level form and they became stationary in its first difference.

With the results of the unit root tests reported in Table 1 it was established that service sector $\left(\mathrm{S}_{\mathrm{t}}\right)$ is integrated to order I (1) and that tele-mobile density rate $\left(\mathrm{TMDR}_{\mathrm{t}}\right)$ is integrated to order one I (1). Testing for bivariate co-integration, the residual, $e_{t}$, yielded the results such that ADF test statistics is -4.6305 (Table 2). The large negative value of ADF statistic implies stationarity of the residual series (integrated to order zero, I (0)). Thus $\mathrm{S}_{\mathrm{t}}$ and $\mathrm{TMDR}_{\mathrm{t}}$ are cointegrated. There exists a long run equilibrium relationship between service sector growth and telecommunication sector growth. Among the studies that investigate the relationship between telecommunication sector and economic growth (GDP), Canning (1999), Chakraborty and Nandi (2003) and Canning and Pedroni (2004) have also concluded that these two variables are cointegrated.

As for multivariate cointegration the results of the Johansen cointegration test indicated four cointegrating relationships within the system which was statistically significant at 5 per cent level (Table 3). Thus the rank of the $\Pi$ matrix is 4 $(r=4)$ which rejects the null hypothesis of no cointegration equation is 3 .

The magnitude of the contribution of telecommunication sector growth to the service sector growth can be obtained by the general (cointegrating) regression output as summarized in Table 4. It is evident that when the growth in tele-mobile density rate $\left(\mathrm{TMDR}_{\mathrm{t}}\right)$ increases by 1 percent service sector growth rate $\left(\mathrm{S}_{\mathrm{t}}\right)$ increases by 0.0356 percent which is statistically significant at 10 per cent. The coefficients are positive implying a positive relationship between the telecommunication sector and service sector.
Having established a long run relationship between service sector growth and telecommunication sector growth the next step is to determine the short run effects. As indicated by Mohanty et al (1996) residuals from the cointegrating equation (error correction term) which represents departure from the long-run equilibrium are included in the ECM to capture the response of service sector growth to any disequilibrium created by the movement in telecommunication sector growth. Thus the error correction model (using growth rate model) yielded the results summarized in Table 5. Since the speed of adjustment coefficient at 1 per cent level it can be concluded that service sector growth responds to disequilibria in the service sector growth - telecommunication sector growth relationship. The negative sign in front of the error correction coefficient indicates that if in this year service sector growth moves away from the equilibrium in the next year it will start falling in order to come back to the equilibrium. The negative value of the speed of adjustment coefficient confirms the system is stable and signifies how quickly the equilibrium is restored.

Under the multivariate analysis the short run effects of the growth rates variables are analyzed using the VEC which translates to about 48 percent of the disequilibrium corrected each year due to changes in the service sector growth rate $\left(\mathrm{S}_{\mathrm{t}}\right)$ and the correction owing to the changes in tele-mobile density rate growth $\left(\mathrm{TMDR}_{\mathrm{t}}\right)$ is about 11 percent. Thus both ECM and VEC models confirmed the existence of the short run dynamics.

As the final step of the estimation process I run the causality tests. The Granger Causality tests the exogeneity of the impact of one variable on another Canning and Pedroni (2004). I find statistical evidence for uni-directional causation running from tele-mobile density rate $\left(\mathrm{TMDRr}_{t}\right)$ to service sector real GDP $\left(\mathrm{Sr}_{\mathrm{t}}\right)$ in the presence of three lags (Table 6). Though this study does not support bi-directional causation empirical evidence for bi-directional causality can be found in Chakraborty and Nandi (2003) and Canning 
and Pedroni (2004), the two studies which looked at the relationship between infrastructure (including telecommunication) and economic growth.

\section{Summary and Conclusions}

The current study is an attempt to fill the gap in the existing literature with the primary objective of investigating the impact of telecommunications on the service sector in Sri Lanka using annual secondary data over the period of 1978 to 2008. I employed bivariate and multivariate cointegration framework and the sample confirmed the research hypothesis that telecommunications sector growth positively contributes to the service sector in the long run. The bivariate cointegration test proved that there has been equilibrium relationship between these two sectors for the period of 1978 to 2008 while the multivariate cointegration framework indicated four such long run relationships in the model. Thus it can be concluded that increase in telecommunications sector growth increases the long run service sector growth.

Both ECM and VEC suggested that the short term disequilibria is corrected (to a certain extent) in the subsequent year. I find evidence that telecommunications contribute to boost the service sector which is uni-directional causation.

This study was limited to the period of 1978 to 2010 due to the absence of dependable data for the period prior to 1978 . To be more precise, the GDP calculations prior to 1978 were not consistent with those of the latter years. This incompatibility in data truncated the sample to only 1978 and forward.

Results imply that growth in telecommunications services foster a source of economic growth through growth in the service sector. There is also evidence that service sector growth causes increased demand for telecommunications. However growth by itself does not guarantee the efficient provision of such services. First step towards promoting a sustainable growth in

telecommunications sector would be formulating complementary regulations aimed at encouraging healthy competition, service quality and cost effectiveness which would overcome the supply bottlenecks of telecommunications services. In addition, utilizing telecommunications to share the information of, for example, prices, job opportunities and markets would enhance the possibility of dispersing growth benefits effectively to different strata of the society. Furthermore, expanding linkage effects of telecommunications services would result in generating more income and employment and Sri Lanka can be developed as a regional communication hub. A preliminary step towards achieving this target would be organizing international communication conferences and exhibitions in the country. Finally, an important measure would be to reduce inequalities in telecommunications services among different regions so that major economic activities are not limited to few cities of the county. There is both theoretical and empirical evidence that better governance seems to engender better services. Hence this policy formulation could be used as means of capturing the benefits of the modern telecommunications technology.

As suggestions for further studies one could check the robustness of the finding by employing different methodology like production function method and growth accounting framework. Furthermore, as frequently done in literature, this study can be extended to investigate the contribution of telecommunications sector (or infrastructure as a whole) to the economic growth of Sri Lanka which would in turn facilitate more comprehensive policy formulation. 


\section{References}

Aschauer, D (1989), Is Public Expenditure Productive?, Journal of Monetary Economics, Vol. 23, No. 2, pp. 177-200.

Asteriou, D \& Hall, S (2007), Applied Econometrics: A Modern Approach, revised edition, Palgrave Macmillan, New York.

Barro, R (1990), Government Spending in a Simple Model of Endogenous Growth, Journal of Political Economy, Vol. 98, pp. 103-105.

Beil, R, Ford, G \& Jackson, J (2003), On the Relationship between Telecommunications Investment and Economic Growth in the United States, Telepolicy Working Paper.

Belaîd, H (2003), Telecommunications Infrastructure and Economic Development, Simultaneous Approach: Case of Developing Countries.

Bougheas, S, Demetriades, P \& Mamuneas T (1999), Infrastructure, Specialization and Economic Growth.

Calderón, C \& Servén, L (2004), The Effects of Infrastructure Development on Growth and Income Distribution, World Bank Policy Research Working Paper No. 3400.

Canning, D (1999), The Contribution of Infrastructure to Aggregate Output, World Bank Policy Research Working Paper No. 2246.

Canning, D \& Pedroni, P (2004), The Effect of Infrastructure on Long Run Economic Growth.

Central Bank, (1981), (1996), (1999), (2008), Annual Reports, Central Bank, Colombo.

Chakaraborty, C \& Nandi, B (2003), Privatization, Telecommunications and Growth in Selected Asian Countries: An Econometric Analysis.

De Mel, D \& Wijayasiri, J (2008), Domestic Preparedness of Sri Lanka with respect to Services Trade Liberalization:

A Case Study of the Telecom Sector, in Domestic Preparedness for Services Trade Liberalization, S Raihan (ed)

CUTS international, Jaipur, pp. 149-177.

Engle, R \& Granger, C (1987), Co-integration and Error Correction: Representation, Estimation and Testing, Econometrica, Vol. 55, No. 2, pp. 251-276.

Estache, A, Speciale, B \& Veredas, D (2005), How Much Does Infrastructure Matter to Growth in Sub-Saharan Africa?.

Fink, C, Mattoo, A \& Rathindran, R (2002), An Assessment on Telecommunications Reforms in Developing

Countries, World Bank Policy Research Working Paper 2909.

Granger, C (1969), Investigating Causal relations by Econometric Models and Cross-Spectral Methods, Econometrica, Vol. 37, No. 3, pp. 424-438.

Hassan, A (2003), Financial Integration of Stock Markets in the Gulf: A Multivariate Cointegration Analysis, International Journal of Business, Vol. 8, No. 3, pp. 335 -346.

Hendry, D \& Juselius, K (2000), Explaining Cointegration Analysis: Part II.

Johansen, S (1988), Statistical Analysis of Cointegration Vectors, Journal of Economic Dynamics and control, Vol. 2, No. 2-3, pp. 231-254.

Jayasuriya, S \& Knight-John, M (2002), Sri Lanka's Telecommunications Industry: from Privatization to Anti-Competition?

Madden, G \& Savage, S (1997), CEE telecommunications Investment and Economic growth, MPRA paper no. 11843.

Mankiw, N, Romer, D \& Weil, D (1992), A Contribution to the Empirics of Economic Growth, The Quarterly Journal of Economics, Vol. 107, No. 2, pp. 407-437.

Mohanty, S, Peterson, W \& Smith, D (1996), Relationships between U.S. and Canadian Wheat Prices: Cointegration and Error Correction Approach, Canadian Journal of Agricultural Economics, Vol. 44, pp. 265-276.

Munnell, A (1992), Policy Watch: Infrastructure Investment and Economic Growth, Journal of Economic Perspectives, vol. 6, no. 4, pp. 189 198.

Narayana, M (2008), Telecommunication Services and Economic Growth: Evidence from India. 
Röller, L \& Waverman, L (2001), Telecommunication Infrastructure and Economic Development: A Simultaneous Approach, The American Economic Review, Vol. 91, No. 4, pp. 909-923.

Seethepalli, K, Bramati, M \& Veredas, D (2008), How Relevant Is Infrastructure to Growth in East Asia?, World Bank Policy Research Working Paper 4597.

Sridhar, K, \& Sridhar, V (2004), Telecommunications Infrastructure and Economic Growth: Evidence from Developing Countries.

Straub, S, Vellutini, C \& Warlters, M (2008), Infrastructure and Economic Growth in East Asia, World Bank Policy Research Working Paper 4589.

Telecommunications Regulatory Commission, (2006), Proposed Ten Year Development Plan (2006-2016).

Torero, M, Chowdhury, S \& Bedi, A (2002), Telecommunication Infrastructure and Economic Growth: A Cross-Country Analysis.

Vijayamohanan, P (2008), Infrastructure, Growth and Human Development in Kerala, MPRA paper no. 7017.

Vuong, V (2008), Mobile Telecommunication Impact on Developing Countries' Growth.

Waverman, L, Meschi, M \& Fuss, M 2005, The Impact of Telecoms on Economic Growth in Developing Countries, Vodafone Policy Paper Series, No. 2, pp. 10-23.

Yoo, S (2002), An Empirical Investigation of Telecommunications Investment and Economic Development in Developing Countries. 


\section{Appendix}

Table 1- Unit Root Test for Levels

\begin{tabular}{lll}
\hline Variable & $\begin{array}{l}\text { ADF Test Statistic and } \\
\text { Significance }\end{array}$ & Order of Integration \\
\hline Service Sector Growth $\left(\mathrm{S}_{\mathrm{t}}\right)$ & $-4.5499^{* * *}$ & $\mathrm{I}(1)$ \\
Telecom. Sector growth $\left(\mathrm{TMDR}_{\mathrm{t}}\right)$ & $-4.3272^{* * *}$ & $\mathrm{I}(1)$ \\
Wholesale \& Retail Trad. growth $\left(\mathrm{W}_{\mathrm{t}}\right)$ & $-4.9689^{* * *}$ & $\mathrm{I}(1)$ \\
Banking \& Finance growth $\left(\mathrm{B}_{\mathrm{t}}\right)$ & $-3.3245^{* * *}$ & $\mathrm{I}(1)$ \\
Ownership of Dwellings growth $\left(\mathrm{Od}_{\mathrm{t}}\right)$ & $-4.1761^{* * *}$ & $\mathrm{I}(1)$ \\
Public Services Growth $\left(\mathrm{Pb}_{\mathrm{t}}\right)$ & $-4.3349^{* * *}$ & $\mathrm{I}(1)$ \\
Private Services Growth $\left(\mathrm{Pr}_{\mathrm{t}}\right)$ & $-3.8621^{* * *}$ & $\mathrm{I}(1)$ \\
\hline \multicolumn{2}{l}{ Note: Intercept and one lag included. The symbols $* * *, * * *$ denote statistical significance at $1 \%}$, \\
5\% and $10 \%$ levels respectively. Time period: $1979-2010(32$ years $)$
\end{tabular}

Table 2 - Engle Granger Cointegration test (unit root (ADF) test of the residual)

\begin{tabular}{|c|c|c|c|}
\hline ADF Test Statistic & -4.630483 & $\begin{array}{l}1 \% \text { Critical Value* } \\
5 \% \text { Critical Value } \\
10 \% \text { Critical Value }\end{array}$ & $\begin{array}{l}-3.6661 \\
-2.9627 \\
-2.6200\end{array}$ \\
\hline
\end{tabular}

*MacKinnon critical values for rejection of hypothesis of a unit root.

Augmented Dickey-Fuller Test Equation

Dependent Variable: D(SPECIFICRESID)

Method: Least Squares

Date: 08/29/11 Time: 13:48

Sample(adjusted): 19812010

Included observations: 30 after adjusting endpoints

\begin{tabular}{lrlrr}
\hline \multicolumn{1}{c}{ Variable } & Coefficient & Std. Error & t-Statistic & Prob. \\
\hline SPECIFICRESID(-1) & -1.408161 & 0.304107 & -4.630483 & 0.0001 \\
D(SPECIFICRESID(- & 0.117221 & 0.192800 & 0.607992 & 0.5483 \\
\multicolumn{1}{c}{ 1)) } & -0.009857 & 0.620302 & -0.015891 & 0.9874 \\
\hline R-squared & 0.633786 & Mean dependent var & 0.097764 \\
Adjusted R-squared & 0.606659 & S.D. dependent var & 5.415507 \\
S.E. of regression & 3.396438 & Akaike info criterion & 5.377971 \\
Sum squared resid & 311.4664 & Schwarz criterion & 5.518091 \\
Log likelihood & -77.66957 & F-statistic & 23.36368 \\
Durbin-Watson stat & 1.978275 & Prob(F-statistic) & 0.000001 \\
\hline
\end{tabular}

\section{Table 3 - Johansen Cointegration Test}

Sample: 19792010

Included Observations: 30

Test assumption: Linear deterministic trend in the data

Series: S TMDR W B OD PB PR

Lag interval: 1 to 1

Likelihood 5 Percent 1 Percent Hypothesized




\begin{tabular}{lllll} 
Eigenvalue & Ratio & Critical Value & Critical Value & No. of CE(s) \\
\hline 0.936110 & 207.0635 & 124.24 & 133.57 & None ** \\
0.779483 & 124.5458 & 94.15 & 103.18 & At most $1 * *$ \\
0.623548 & 79.19239 & 68.52 & 76.07 & At most 2** \\
0.561084 & 49.88346 & 47.21 & 54.46 & At most 3* \\
0.397984 & 25.18005 & 29.68 & 35.65 & At most 4 \\
0.219721 & 9.955896 & 15.41 & 20.04 & At most 5 \\
0.080348 & 2.512791 & 3.76 & 6.65 & At most 6 \\
\hline *(**) denotes rejection of the hypothesis at 5\% (1\%) significance level. \\
L.R. test indicates 4 cointegrating equation(s) at 5\% significance level.
\end{tabular}

\section{Table 4 - Cointegrating Regression Output}

Dependent Variable: S

Method: Least Squares

Date: 08/16/11 Time: 15:33

Sample: 19792010

Included observations: 32

\begin{tabular}{crllr}
\hline Variable & Coefficient & Std. Error & t-Statistic & Prob. \\
\hline TMDR & 0.035569 & 0.019620 & 1.812872 & 0.0819 \\
W & 0.362765 & 0.053733 & 6.751248 & 0.0000 \\
B & 0.175272 & 0.045625 & 3.841538 & 0.0007 \\
OD & 0.042322 & 0.023517 & 1.799657 & 0.0840 \\
PB & 0.146131 & 0.046557 & 3.138756 & 0.0043 \\
PR & 0.042817 & 0.059946 & 0.714248 & 0.4817 \\
C & 0.563931 & 0.818143 & 0.689282 & 0.4970 \\
\hline R-squared & 0.800449 & Mean dependent var & 6.526622 \\
Adjusted R-squared & 0.752557 & S.D. dependent var & 3.395904 \\
S.E. of regression & 1.689246 & Akaike info criterion & 4.077082 \\
Sum squared resid & 71.33883 & Schwarz criterion & 4.397712 \\
Log likelihood & -58.23331 & F-statistic & 16.71357 \\
Durbin-Watson stat & 2.339236 & Prob(F-statistic) & 0.000000 \\
\hline
\end{tabular}

\section{Table 5 - Error Correction Model}

Dependent Variable: $\mathrm{D}(\mathrm{S})$

Method: Least Squares

Date: 08/29/11 Time: 18:29

Sample(adjusted): 19802010

Included observations: 31 after adjusting endpoints

\begin{tabular}{lrllr}
\hline \multicolumn{1}{c}{ Variable } & Coefficient & Std. Error & t-Statistic & Prob. \\
\hline \multicolumn{1}{c}{ D(TMDR) } & 0.115603 & 0.044077 & 2.622733 & 0.0140 \\
ERROR(-1) & -1.258183 & 0.175310 & -7.176912 & 0.0000 \\
\multicolumn{1}{c}{ C } & -0.061204 & 0.577814 & -0.105923 & 0.9164 \\
\hline R-squared & 0.678513 & Mean dependent var & 0.055591 \\
Adjusted R-squared & 0.655550 & S.D. dependent var & 5.478778 \\
S.E. of regression & 3.215489 & Akaike info criterion & 5.265601 \\
Sum squared resid & 289.5023 & Schwarz criterion & 5.404374 \\
Log likelihood & -78.61682 & F-statistic & 29.54765 \\
Durbin-Watson stat & 1.918998 & Prob(F-statistic) & 0.000000 \\
\hline
\end{tabular}


Table 6 - Granger Causality Test

\begin{tabular}{llll}
\hline Direction of Causality & F value & Probability & Decision \\
\hline $\mathrm{TMDRr}_{\mathrm{t}}$ does not Granger cause $\mathrm{Sr}_{\mathrm{t}}$ & $2.4347^{*}$ & 0.0919 & Reject \\
$\mathrm{Sr}_{\mathrm{t}}$ does not Granger cause $\mathrm{TMDRr}_{\mathrm{t}}$ & 0.2046 & 0.8921 & Do not Reject \\
\hline
\end{tabular}

Note: $(*)$ denotes significance at $10 \%$

\section{Figure 1 - Growth Trend in Tele-Mobile Density Rate (TMDR) and Service Sector}

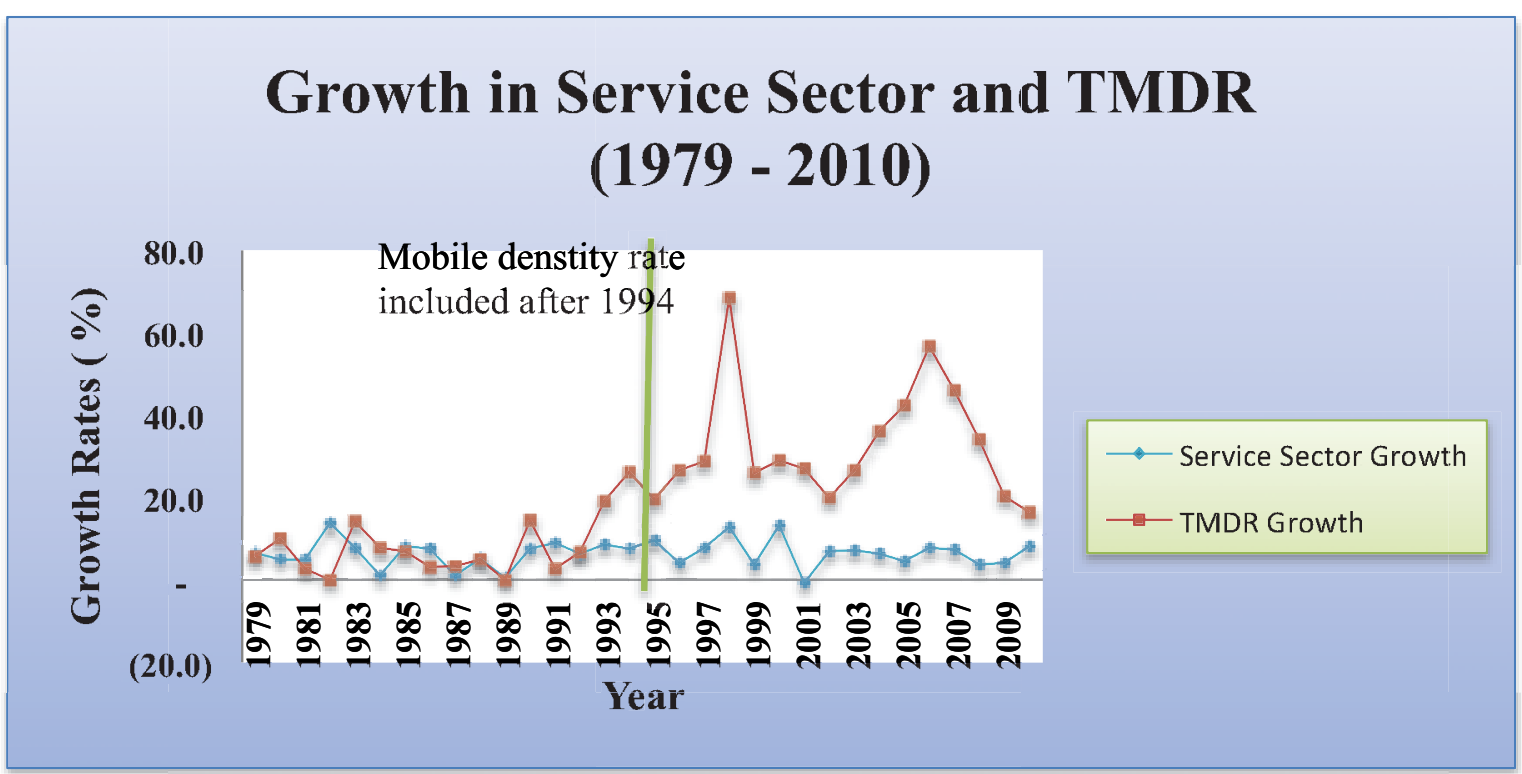

Data source: Cental Bank Annual Reports various issues

Figure 2 - Significance of the Transport, Storage and Communication Sector within the Service Sector

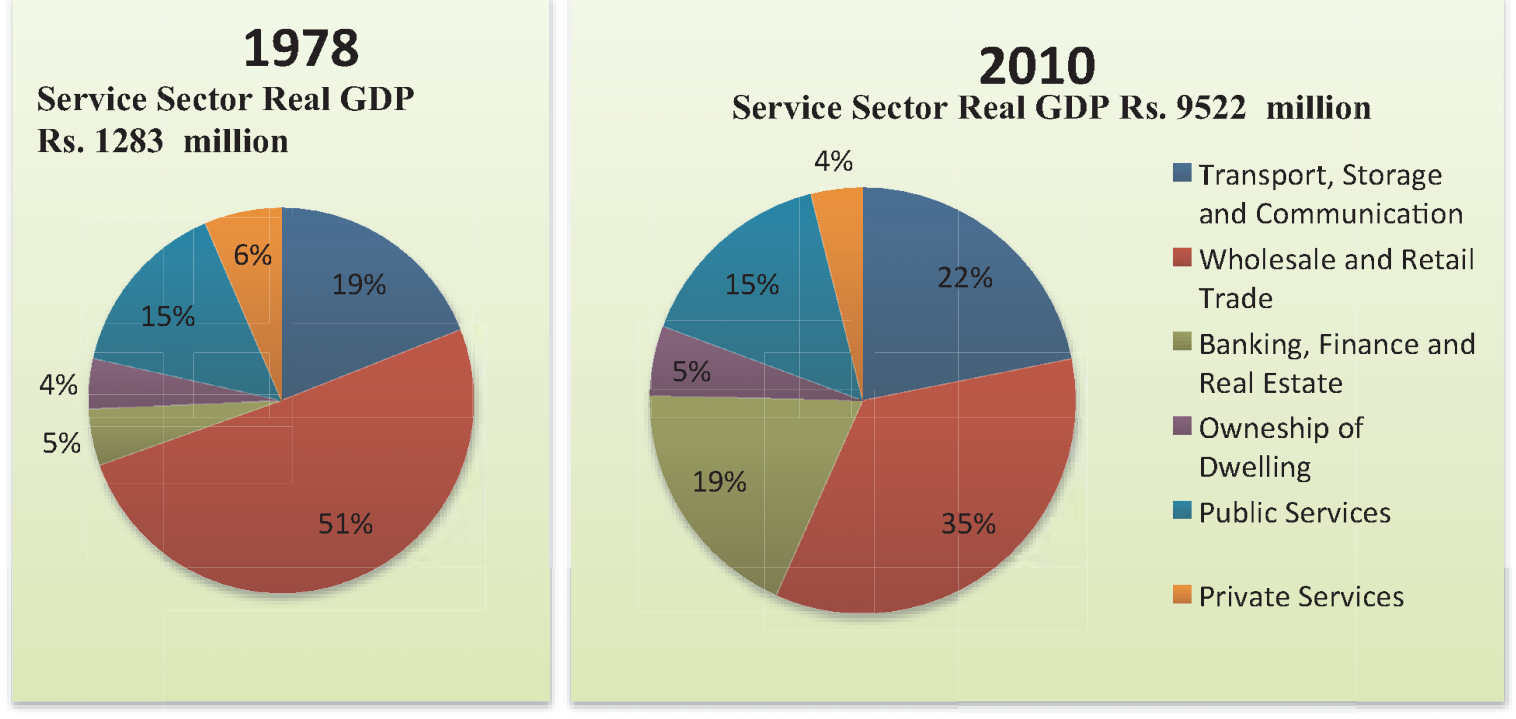

Data Source : Central Bank Annual Reports (1978 and 2010) 